Ms Lucia Nthooa Lisene

University of the Free State,

School of Education Studies

Dr Thuthukile Jita

University of the Free State,

School of Education Studies

DOI: $h t t p: / / d x . d o i$. org/10.18820/2519593X/pie.

v36i1.8

ISSN 0258-2236

e-ISSN 2519-593X

Perspectives in Education

2018 36(1): 111-127

(c) UV/UFS

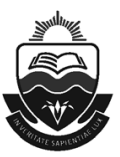

\section{Exploring the integration of modern technologies in the teaching of physical science in Lesotho}

\begin{abstract}
The aim of the paper is to explore the knowledge base of high school physical science teachers, from selected high schools in Lesotho, regarding the integration of information and communication technologies (ICTs) into the curriculum. The new physical science curriculum in Lesotho requires the use of ICTS for teaching. The teachers' use of ICTS was explored through a questionnaire based on the technological pedagogical content knowledge model (TPACK). Data were analysed using the statistical analysis software (SAS) and the results showed that $77 \%$ of the teachers used ICTs for teaching, while $80 \%$ used them for non-teaching activities. The mean score for teachers' TPACK was 2.88. This score is below the average of three for the Likert points of the items on teachers' TPACK, which was set as the acceptable level for this paper. Therefore, the study concludes that Lesotho teachers do use ICTs for teaching physical science even though their TPACK may be below average. Their low TPACK may be an indication that they used ICTs to get more information about the content, rather than for delivering the lessons. There is thus an urgent need to increase the support for teachers to maximise the use of ICTs for teaching.
\end{abstract}

Keywords: ICTS, ICT integration, TPACK, physical science, constructivism

\section{Introduction}

Scholars have already established the importance of ICTs for teaching (Abdullahi, 2014; UNESCO, 2014). Some research also suggests that most teachers are optimistic about the integration of ICTs as a strategy to improve instruction (Aslan \& Zhu, 2016; Peralta \& Costa, 2007). As learners, in many countries, are often surrounded by modern technologies, there is a need for educators to take advantage of ICTs in the school and classroom settings. However, in practice some teachers struggle to translate their positive attitudes and availability of ICT infrastructure into actual ICT integration despite the improvements made towards their technical training on ICTs (Rastogi \& Malhotra, 2013; Zehra \& Bilwani, 2016). As a result, it is important to 
continue to examine teachers' knowledge on ICT integration in order to collect the evidence required for development of improvement strategies.

Some of the barriers of ICT integration as identified by teachers include lack of confidence, insufficient time, inappropriate software, inaccessibility of ICT resources, limitations of the curriculum, insufficient support and lack of knowledge related to ICT integration, among others (Alkahtani, 2016; Prasad, Lalitha \& Strikar, 2015). Chigona, Chigona and Davids (2014) assert that the context of the school can also be a barrier to ICT integration because it can discourage teachers from using ICTs, such as when they are teaching very large classes. Ward (2003), however, believes that it is sometimes the teachers who use their school contexts to make limited choices and relates the problem to inadequate institutionalisation. Teachers with positive attitudes are more likely to overcome some of these barriers, either individually or in collaboration with others. Consequently, in the absence of conclusive evidence on what hinders ICT integration in the classrooms especially in developing countries, it is important to continue with investigations related to ICT integration in various contexts. This paper therefore examines teachers' knowledge related to ICT integration into physical science in Lesotho.

Although a few studies have been conducted in Lesotho on the subject of ICT integration (Chere-Masopha, 2011; Kalanda \& De Villiers, 2013; Ntoi, 2007; Olatokun \& Ntemana, 2015), there are gaps in terms of their focus and/or approaches. For instance Chere-Masopha (2011), explored ICT integration by secondary level teachers in general with no specific subject focus. ICT-integration is likely to vary based on the nature of the subject, the teaching thereof, and perhaps the availability if ICT-related material in that subject. The focus on physical science, specifically, is thus important in the context of the country's curriculum framework that specifically advocates for such integration. Similarly, Olatokun and Ntemana (2015) studied ICT integration by university lecturers, but neither focused on specific subjects nor on the prescribed secondary school curriculum. Methodologically, Kalanda and De Villiers (2013) approached their study through a participatory action research design while Ntoi (2007) conducted a qualitative case study. The present article reports on a quantitative study that focuses on ICT integration in the high school physical science subject area.

\section{Research objectives}

The study aimed at exploring the types of knowledge of Lesotho physical science teachers in relation to the integration to the integration of information and communication technologies (ICTs) into the curriculum. We examined the ICTs used and how was it used. The research tested the null hypothesis that high school teachers in Lesotho do not have the types of knowledge required for the integration of ICTs in their teaching of physical science.

\section{Research questions}

The following research questions were explored: 1 . How physical science teachers in Lesotho high schools use ICTs for teaching? 2. Which ICTs do they use? 3. What type of knowledge do they have with regard to the integration of ICTs in their subject?

\section{Background to the study}

The lack of knowledge on ICT integration into the daily instructional activities in schools is a global challenge (Lau \& Sim, 2008). In Lesotho, the officials in the Ministry of Education and Training (MoET) intertwine this lack of knowledge with the shortage of technical support 
for teachers (Farrell, Isaacs \& Trucano, 2007). Part of the reasons may include the lack of knowledge about the status of ICT integration in the country and/or lack of supervisory capacity in the country. The role of ICTs in supporting growth and development in Lesotho has been enshrined in several policy pronouncements (Morgan-Jarvis, 2015). For instance, the policy on the use of ICTs, which was developed in 2005, earmark learning institutions as some of the main role players in the implementation of the ICT policy (Lesotho government, 2005). The aims of the national vision 2020 , which is the basis for the ICT policy, include ensuring a strong foundation for technology research and development in the country (Lesotho government, 2002). This aim emphasises a strong link between science and technology curricula, which is part of the reason for conducting the study on how teachers integrate technology into physical science.

The examinations council of Lesotho (ECoL) expects physical science teachers to integrate ICTs when they deliver content knowledge (ECoL, 2012). The physical science syllabus forms part of the new Lesotho general certificate of secondary education (LGCSE) curriculum which demands acquisition of technological and communication skills by the learners. The relatively new physical science syllabus, which dates back to 2012, is the focus of this paper. The paper explores how teachers have responded to the call by the LGCSE curriculum for the use of ICTs in the teaching and learning of physical science. The literature and framework which form basis of the paper will be discussed first, followed immediately by the methodology, and finally by the discussion of the results and conclusions respectively.

\section{Theoretical framework and literature review}

This paper views the concept of ICT integration through two lenses, namely the model of constructivism learning theory in e-learning environments and the technological pedagogical content knowledge (TPACK) model. The learning theories such as behaviourism, humanism and constructivism, among others, have consistently influenced the designing of instruction and as such, designs that embrace theories of learning can potentially have a positive impact on ICT integration (Koohang, 2004). The model of constructivism learning theory in e-learning environments is a learner-centred strategy for integrating ICTs into instructional activities aimed at encouraging learners to use their experiences to formulate new knowledge in an active manner (Koohang et al., 2009; Wang, 2008). The TPACK model has a potential to explain the complex nature of ICT integration into teaching, and allows teachers to reflect on their own practice for professional development (Messina \& Tabone, 2012; Shu, 2016).

\section{Constructivism learning theory in e-learning environments}

Koohang developed the model of constructivism learning theory in e-learning environments in 2009 with the aim of explaining how teachers can involve learners in the process of knowledge construction (Koohang et al., 2009). Constructivism advocates for learners to be allowed to use their existing knowledge to actively create new knowledge (Vygotsky, 1978). Cognitive constructivism focuses on the ability of the individual learners to interpret their own experiences in their formulation of new knowledge, thus being engaged in their own learning (Wan, 2014; Wang, 2008). Social constructivism emphasises teaching in an environment that is conducive for learning contextually and authentically through cooperation, interaction and communication (Lever-Duffy \& McDonald, 2011). ICTs provide such an environment by enabling the learners to learn in a collaborative setting where they interact amongst themselves and with subject experts. Drijvers et al.'s (2013) and Mouza et al.'s studies (2014) were 
underpinned by constructivism as their framework and they confirm that research continues to view constructivism as a suitable theory for ICT interaction.

The model consists of instructional design elements and assessment elements as its main components. There are two types of design elements. These are the fundamental elements that deal with individual aspects of learning strategies such as exploration, high-order thinking skills, learners' pre-knowledge, authentic examples and scaffolding, as well as collaborative elements that include social interaction and cooperation (Koohang et al., 2009). The diagram also illustrates assessment, which can be performed by the learners on themselves or in groups as well as by the teachers. The model is diagrammatically depicted as follows:

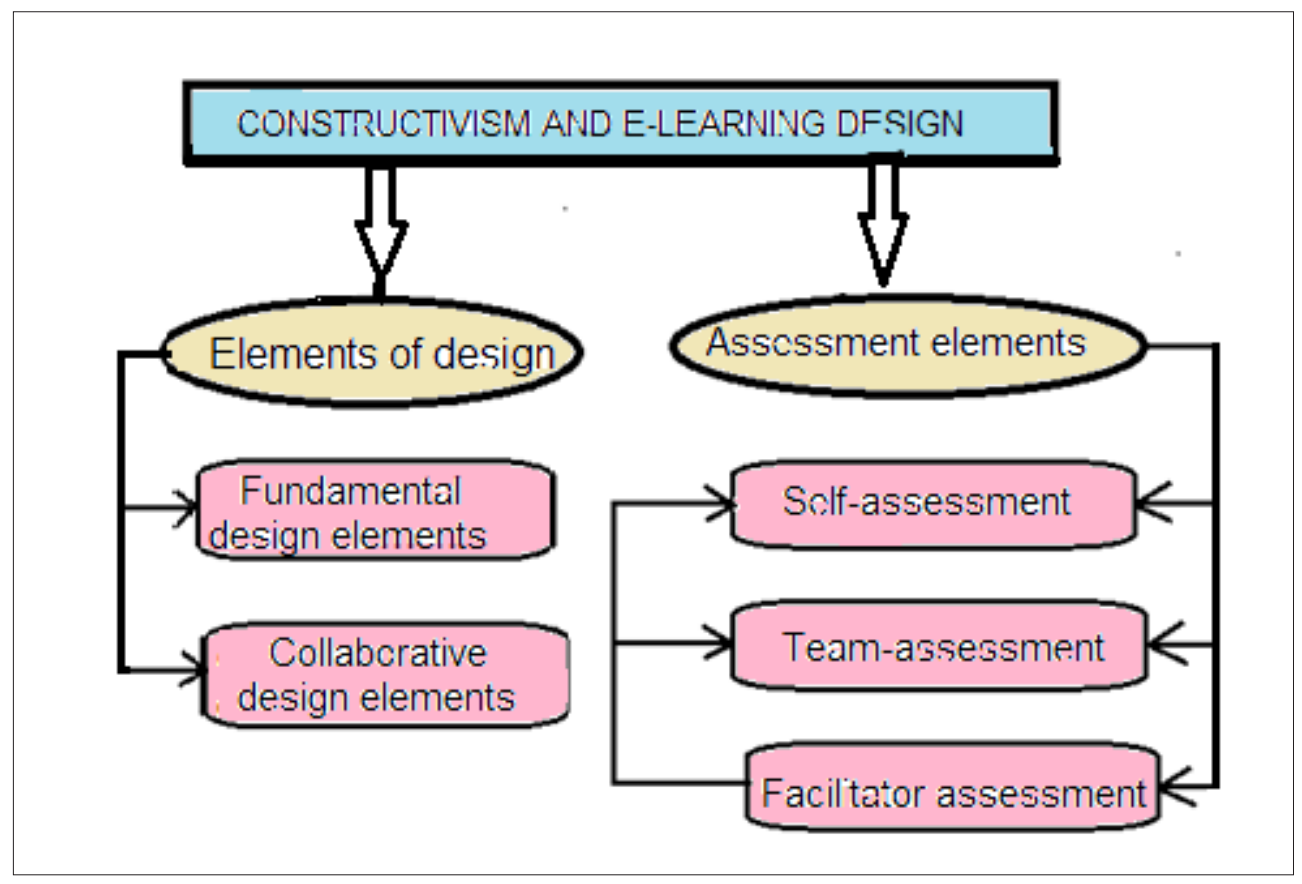

Figure 1: Constructivism elements and e-learning design learning activities; Adapted from Koohang et al. (2009:95)

\subsection{Technological pedagogical content knowledge (TPACK) model}

The TPACK model was proposed by Mishra and Koehler in 2006 to provide a framework through which people could deal with complications of ICT integration after many years of empirical research (Koehler \& Mishra, 2008). Teaching is intricate as it is based on various types of knowledge, including understanding the educational programme and the learners' ways of thinking and learning (Chai et al., 2013; Mishra \& Koehler, 2006).

The type of knowledge that an individual has is highly contextualised because it affect culture, socio-economic status and ability to plan, among other factors (Harris \& Hofer, 2011). The surfacing of digital ICTs forms part of the contemporary context and hence necessitated the addition of technological knowledge (TK) by Mishra and Koehler to Shulman's original idea of pedagogical content knowledge (PCK). Consequently, the TPACK model has been widely used to explore the use of ICTs by pre-service and in-service teachers (Maher, 2013). 
However, most TPACK studies observed pre-service teachers rather than in-service teachers. Most TPACK studies also dealt with the integration of ICTs into general teaching rather than teaching of individual subjects (Wu, 2013). This paper thus focused on ICT integration into physical science, in particular.

Figure 2 is a representation of the contexts and the types of knowledge that they influence.

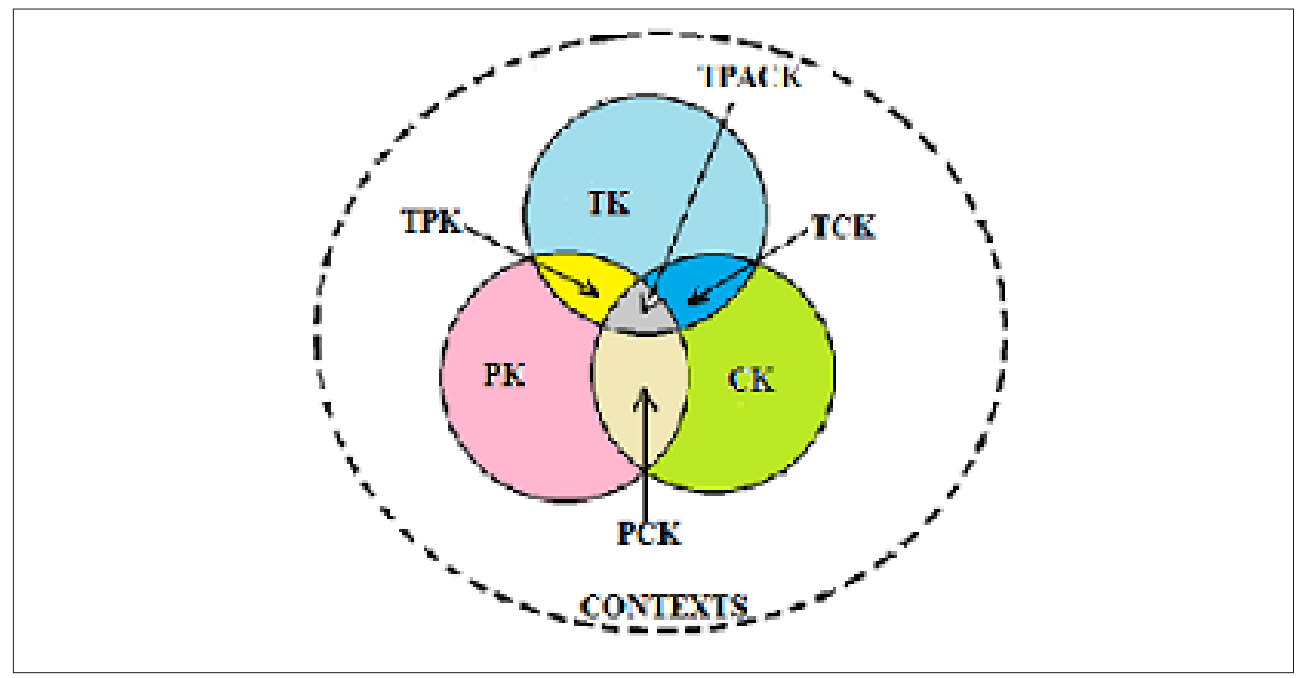

Figure 2: Technological pedagogical content knowledge (TPACK) model. Adapted from Koehler et al. (2013:3)

The three circles represent the main categories of knowledge i.e., technological knowledge (TK), pedagogical knowledge (PK) and content knowledge (CK). The main categories of knowledge intersect in pairs to form three more types of knowledge, namely technological pedagogical knowledge (TPK), technological content knowledge (TCK) and pedagogical content knowledge (PCK). All three main categories interconnect to form the technological pedagogical content knowledge (TPACK).

The literature explored in this section confirms that knowledge is highly dynamic and as such requires to be regularly interrogated. The circumstances that surround us influence the type of knowledge we develop. Both models outline the application of the knowledge of ICTs for teaching. According to Chai et al. (2011), TPACK is the knowledge of enhancing learning of a particular content by applying suitable pedagogical and technological methods. Koohang and Harman (2005) define e-learning as the process of imparting knowledge through technology. Both models, therefore, emphasise the appropriate use of pedagogy and technology to deliver the content of the subject.

\section{Methodology}

\subsection{Research approach, paradigm, design and process}

The present study followed the quantitative approach, a deductive paradigm guided by postpositivism to allow the researchers to be objective, logical and systematic when testing the hypothesis (Leedy \& Ormrod, 2013; Higgs, 1996). The descriptive non-experimental survey 
design, which was adopted enabled the researchers to focus on exploring the knowledge of a large population of teachers through only a small sample because of its flexibility and adaptability (Mulwa et al., 2012). This principle further enabled the description of ICT integration without manipulating the school contexts or explaining the cause-effect relations between teachers' knowledge and teachers' age, teaching experience, gender or place of work (Johnson \& Christensen, 2014).

\subsection{Population and sample of the study}

The target population consisted of 138 high schools, which offer physical science as a subject (ECoL, 2013). A sample of 23 schools and 76 teachers was selected from five of the ten districts of Lesotho, namely Mafeteng, Maseru, Berea, Leribe and Mokhotlong. The districts consist of places in the highlands, lowlands, urban areas as well as rural areas for a fair representation of the population schools in terms of their location that may affect availability of technological resources. Leedy and Ormrod (2005) suggest that if the population size is greater than 100 but around 500 , then a sample size should be $50 \%$ of the population. Based on this argument, the sample intended for the present study consisted of 74 schools, but the response rate was low and thus the study resulted in 23 schools.

\subsection{Sampling techniques}

A random cluster sample of schools was selected through StatTrek table of random numbers by giving the schools numbers that were fed into the table to choose the stipulated number of school (StatTrek, 2016). A random sample has the accuracy, efficiency, validity and reliability required for generalising the conclusions of the study to the entire population (Mathers, Fox \& Hunn, 2009). Random sampling minimised costs and time while still ensuring reasonable representation of the population (Creswell, 2013). The cluster method was preferred because the individual teachers were located in separated places that would otherwise be difficult to reach. The basic one-stage cluster method was chosen because each school had only few physical science teachers who were all asked to participate.

\subsection{Data collection and analysis}

The respondents filled in a questionnaire consisting of 29 closed-ended items. The data collected included the teachers' demographic details, knowledge and use of ICTs. Items 1 to 23 were based on the TPACK model with a 5-point Likert scale ranging from $1=$ No knowledge at all to $5=$ Complete knowledge. Items 24 up to 29 were employed to establish whether the teachers were integrating ICTs into teaching, also with a 5-point scale with the rating range from $1=$ None at all to $5=$ Always. The questionnaires were delivered to the schools and then collected as soon as they had been filled in. Some forms were not completed in full, which resulted in inclusion of the last weighting (11=no response) for purposes of data analysis.

Percentages of the responses to the biographical questions were calculated using the statistical analysis software (SAS) frequency procedure (SAS, 2013). This software seems to be widely used in recent years particularly in research related to ICT integration (Alkahtani, 2016). Descriptive statistics were calculated for the mean scores for the entire sample ('All') and by gender, age group, teaching experience, type of school and location of school through the SAS tabulate procedure (SAS, 2013). The respondents were grouped into various categories of the biographical variable in question because all the biographical variables were categorical. The mean for the different domains (types of knowledge) of the demographic groups was contrasted through one-way analysis of variance (ANOVA) using 
the SAS general linear model procedure (SAS, 2013). The sum score in question was the dependent variable whereas the stipulated biographical variable was the single factor in the ANOVA model.

\subsection{Reliability and validity}

A pilot study was conducted on ten teachers and the required adjustments were made the questionnaire to facilitate a high response rate and reduce the errors for reliability and validity. The effect of confounding variables on the teachers' knowledge and use of ICTs was explored to augment the internal validity. The external validity was improved by using a random sample (Bhattacherjee, 2012). The Cronbach's alphas between 0.69 and 0.90 obtained indicated that all the items were reliable for measuring teachers' knowledge (Tavakol \& Dennick, 2011). These alpha coefficients are comparable with those obtained by Schmidt et al., (2009) which ranged between 0.82 and 0.92 .

\subsection{Ethical considerations}

The University of the Free State granted the ethical clearance for this study. Permission for teachers' participation in the study was sought in writing from the Ministry of Education and Training and from the principals. The volunteers were requested to complete a consent form emphasising the significance of the study and the respondents' right to participate in and/or withdraw from the study at any time (Leedy \& Ormrod, 2005). The respondents were assured that they would not be exposed to any possible harm. Privacy and confidentiality were observed by using numbers on the research instruments and keeping all the completed questionnaire forms in a safe place (Johnson \& Christensen, 2014).

\section{Results and discussions}

In this section, the results are presented in tables and charts then discussed. The demographic details of the participants are presented first, followed by the discussion of the results on the use of ICTs and the knowledge of teachers related to the integration of ICTs, respectively.

\subsection{Demographic data}

Table 1 below shows the demographical data of the 76 participants from the 23 schools that constituted the sample used in the paper.

Table 1: Teacher's demographic data

\begin{tabular}{|c|c|c|c|c|c|c|c|c|c|c|c|c|}
\hline & \multicolumn{2}{|c|}{ Age (missing = 3) } & \multicolumn{2}{|c|}{$\begin{array}{c}\text { Gender } \\
\text { (missing = 5) }\end{array}$} & \multicolumn{2}{c|}{$\begin{array}{c}\text { Experience in } \\
\text { number of years } \\
\text { (missing = 4) }\end{array}$} & \multicolumn{2}{c|}{ Type of school (missing = 3) } & \multicolumn{2}{c|}{$\begin{array}{c}\text { Location of school } \\
\text { (missing = 4) }\end{array}$} \\
\hline Group & $20-29$ & $30-39$ & $40+$ & male & female & $0-4$ & $5-14$ & $15+$ & Government & Non-government & Lowlands & Highlands \\
\hline$\%$ & 20.6 & 53.4 & 26.0 & 69.0 & 31.0 & 27.8 & 51.4 & 20.8 & 12.3 & 87.2 & 88.9 & 11.1 \\
\hline
\end{tabular}

Results in table 1 illustrate that the number of males (69.0\%) was higher than that of females $(31.0 \%)$. The following groups of teachers were also larger than the rest of the groups within the same variable; teachers aged between 30 and $39(53.4 \%)$, teachers with 5 to 14 years 
of experience (51.4\%), teachers from non-government schools (87.2\%) and teachers from schools in the lowlands of the country $(88.9 \%)$.

\subsection{The use of ICTs}

The following table illustrates the results of the teachers' use of ICTs including the means for how often they use the ICTs.

Table 2: Teachers' use of ICTs

\begin{tabular}{|c|l|c|c|}
\hline \multirow{2}{*}{ Category } & \multicolumn{1}{|c|}{ Results } & Teaching activities & Non-teaching activities \\
\hline \multirow{3}{*}{ Use of ICTs } & Positive & $77 \%$ & $80 \%$ \\
\cline { 2 - 4 } & Negative & $33 \%$ & $20 \%$ \\
\hline \multirow{2}{*}{ Frequency } & Mean & 2.5 & 3.4 \\
\cline { 2 - 4 } & S. dev. & 1.08 & 1.15 \\
\hline
\end{tabular}

The results in table 2 show that $77 \%$ of the teachers used ICTs for teaching and $80 \%$ used them for non-teaching activities. There were slightly more teachers who used ICTs for nonteaching activities than those who used them for teaching. The mean of the Likert points is 3 which is the sum of all five points divided by $5(1+2+3+4+5=15 \div 5=3)$. This was set as the acceptable level of responses for this paper (Nwanekezi, Onyekuru \& Oragwu, 2011). The mean scores for the frequency of the use of ICTs were 2.5 for teaching activities and 3.4 for non-teaching activities. The mean for teaching activities was below the acceptable level of responses $(M=3)$, while the mean for non-teaching activities was slightly above the acceptable level. Both means can be rounded off to Likert point 3 which represents "sometimes, about once a week". These findings indicate that teachers employ some technological skills inside and outside their classrooms. However, the fact that teachers used ICTs more for non-teaching activities than they do for teaching itself and that they only use them occasionally may be regarded as an indication that they use the technologies to perform their traditional duties (Haddad, Ferreira \& Faria, 2014). For instance, they may be using the Internet to strengthen their content knowledge rather than for presenting it to their learners.

The standard deviations were 1.08 for teaching activities and 1.15 for non-teaching activities (table 2). These results demonstrate that in both cases the results were close to the mean and therefore the two extremes on the questionnaire (viz. 1=None at all or $5=$ daily), were not common. These results were to be expected, as Kalanda and De Villiers (2013) observe that the use of ICTs in Lesotho is increasing. 
The figure (3) indicates the types of technologies used and the frequency of their use.

\section{frequency of use of technologies}

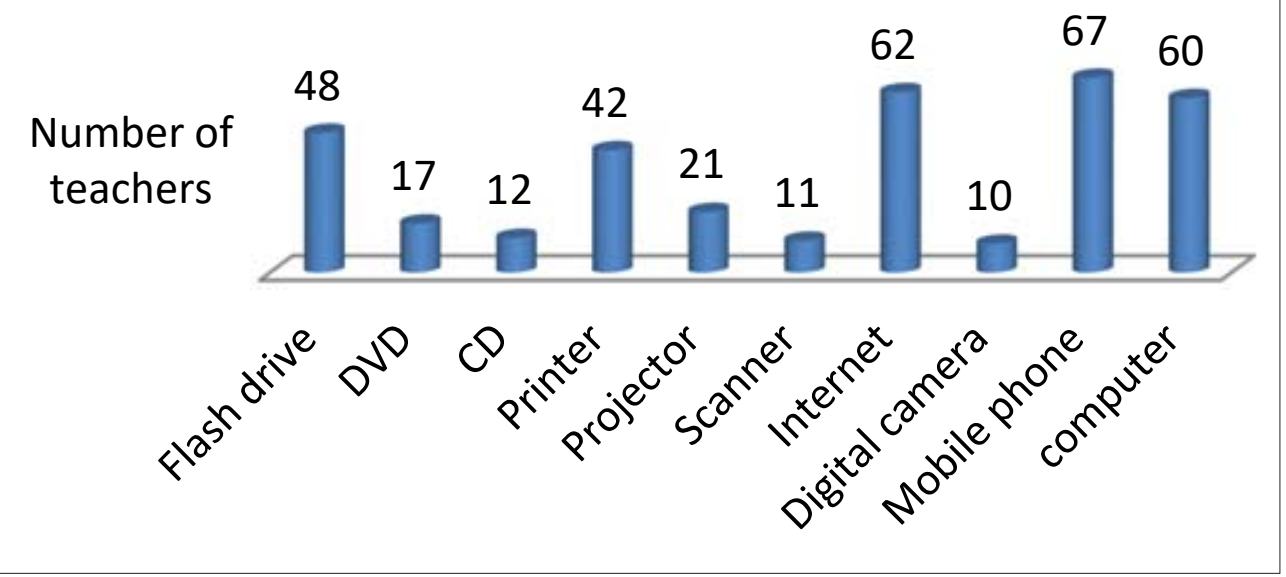

Figure 3: Technologies used by teachers $(n=76$ but the teachers chose more than one technology)

Figure 3 shows the numbers of teachers using various technologies as 67 for mobile phones, 62 for the Internet and 60 for computers. Ten teachers used digital cameras, 11 teachers used scanners and 12 teachers used CDs. This shows that mobile phones, the Internet and computers were among the technologies that were mostly used in schools, while digital cameras, scanners, CDs and DVDs were among those that were rarely used. The rest of the technologies were used in moderation. Digital cameras were probably not widely used because smart phones and computers have built-in cameras, which are more convenient to use. CDs and DVDs were probably replaced with flash drives, which are more durable. This also demonstrates that teachers probably used mobile phones more than computers to access the Internet. This was to be expected because teachers have more access to their mobile phones than to the school computers. They access the Internet and other services more easily through their phones, thus reducing the problem of a lack of access to ICT resources (Mulwa et al., 2012).

\subsection{Teachers' knowledge}

The seven domains of knowledge that we explored are technological knowledge (TK), pedagogical knowledge (PK), content knowledge (CK), technological pedagogical knowledge (TPK), pedagogical content knowledge (PCK), technological content knowledge (TCK) and technological pedagogical content knowledge (TPACK).

Figure 4 and table 3 show the descriptive results for various domains of teachers' knowledge. Figure 4 shows the overall means and standard deviations while table 3 show the means and standard deviations for different groups of teachers. 


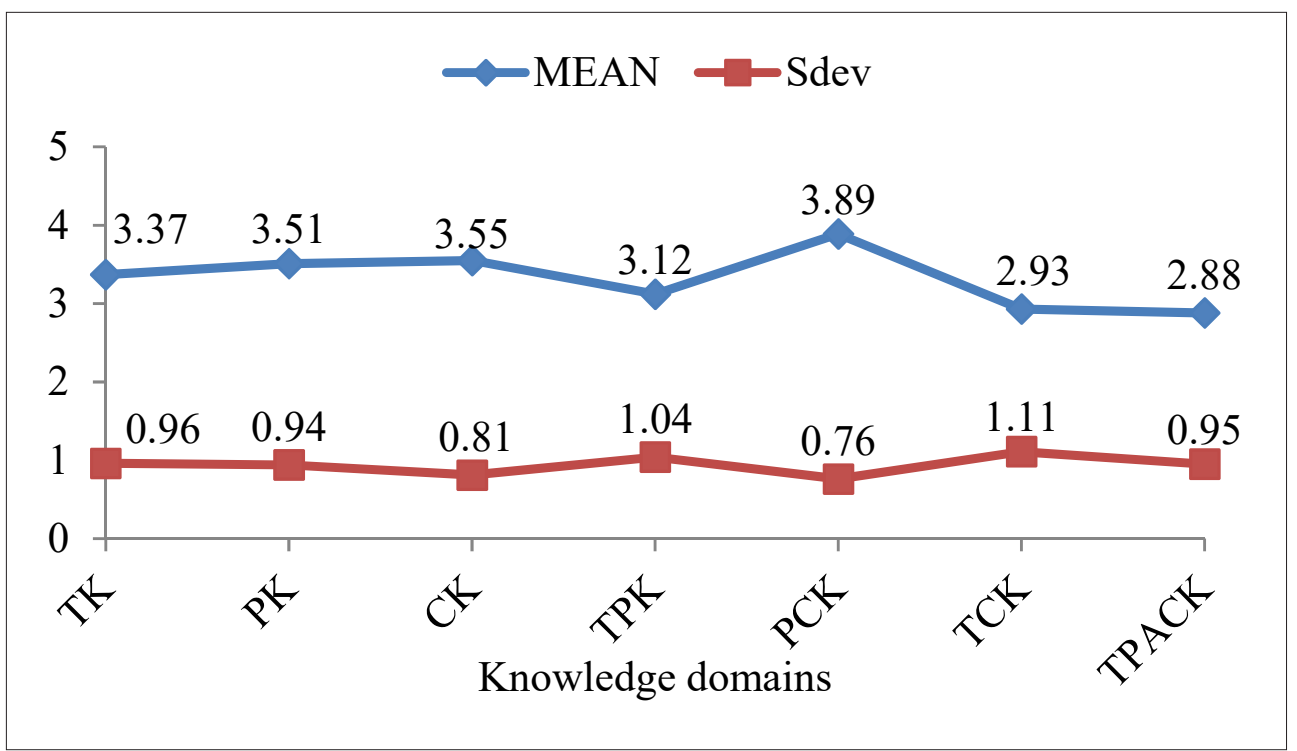

Figure 4: Overall descriptive results $(n=76)$

The descriptive statistics (figure 4 and table 3 ) indicate that the standard deviation values ranged from 0.4 to 1.6 . These results demonstrate more similarities than differences within and between the groups of teachers because the standard deviations were low. The teachers who have taught for 15 years or more had the highest standard deviations of 1.4 to 1.6 for the types of knowledge that integrate technology, namely TPK, TCK and TPACK (table 3). This variation indicates that some of the teachers may consider themselves technophobic because they had not received formal technological training (Chigona et al., 2014).

The overall mean scores for all domains of knowledge ranged between 2.88 and 3.89 (figure 4). These scores are above the acceptable level of 3 except for the scores of TCK $(\mathrm{M}=2.93)$ and TPACK $(\mathrm{M}=2.88)$. The mean scores for CK and PCK range between 3.3 and 4.3 (figure 4 and table 3), and hence were above the acceptable level for all groups of teachers. This means that most of the teachers had more than the moderate level (Likert point 3 ) of CK and PCK. The mean score for PCK was the highest at 3.89 and the mean score for TPACK was the lowest at 2.88 (figure 4). The mean score for female teachers $(M=2.70)$ was the only mean lower than the overall score for TPACK. The high score for PCK and the low score for TPACK corroborate Messina and Tabone's (2012) findings viz. 4.28 and 2.88 respectively. 
Table 3: Descriptive statistics for various groups of teachers

\begin{tabular}{|c|c|c|c|c|c|c|c|c|c|c|c|c|c|c|c|}
\hline \multirow{2}{*}{$\begin{array}{l}\frac{0}{0} \\
\frac{\pi}{\frac{\pi}{2}} \\
>\end{array}$} & \multirow{2}{*}{$\begin{array}{l}\text { Group of } \\
\text { teachers }\end{array}$} & \multicolumn{2}{|c|}{ TK } & \multicolumn{2}{|c|}{ PK } & \multicolumn{2}{|c|}{ CK } & \multicolumn{2}{|c|}{ TPK } & \multicolumn{2}{|c|}{ PCK } & \multicolumn{2}{|c|}{ TCK } & \multicolumn{2}{|c|}{ TPACK } \\
\hline & & $M$ & SD & $\mathrm{M}$ & SD & $\mathrm{M}$ & SD & $M$ & SD & $M$ & SD & $M$ & SD & $\mathrm{M}$ & SD \\
\hline \multirow{2}{*}{ 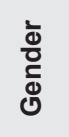 } & Female $(n=22)$ & 3.2 & 0.9 & 3.5 & 1.2 & 3.6 & 1.0 & 2.9 & 1.2 & 4.2 & 0.7 & 3.0 & 1.0 & 2.7 & 1.0 \\
\hline & Male $(n=49)$ & 3.5 & 1.1 & 3.6 & 0.3 & 3.5 & 0.7 & 3.2 & 1.0 & 3.7 & 0.7 & 2.8 & 1.2 & 2.9 & 0.9 \\
\hline \multirow{3}{*}{ 名 } & $20-29(n=15)$ & 3.9 & 0.6 & 3.9 & 0.7 & 3.5 & 0.7 & 3.2 & 0.9 & 3.8 & 0.7 & 3.5 & 1.0 & 3.2 & 0.6 \\
\hline & $30-39(n=39)$ & 3.5 & 1.0 & 3.6 & 1.0 & 3.5 & 0.9 & 3.1 & 1.1 & 3.8 & 0.8 & 2.9 & 0.9 & 2.8 & 0.9 \\
\hline & $40+(n=19)$ & 2.9 & 1.1 & 3.3 & 1.2 & 3.6 & 1.0 & 3.0 & 1.3 & 4.1 & 0.8 & 2.5 & 1.6 & 2.9 & 1.4 \\
\hline \multirow{3}{*}{ 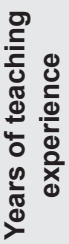 } & $0-4(n=20)$ & 3.6 & 0.9 & 3.6 & 0.8 & 3.5 & 0.7 & 3.2 & 0.9 & 3.8 & 0.7 & 3.1 & 1.0 & 3.1 & 0.7 \\
\hline & $5-14(n=37)$ & 3.4 & 1.0 & 3.6 & 1.0 & 3.4 & 0.8 & 3.1 & 1.1 & 3.8 & 0.8 & 3.0 & 1.1 & 2.8 & 0.9 \\
\hline & $15+(n=15)$ & 3.0 & 1.2 & 3.2 & 1.2 & 3.8 & 1.1 & 3.1 & 1.4 & 4.3 & 0.6 & 2.7 & 1.6 & 2.9 & 1.5 \\
\hline \multirow{3}{*}{ 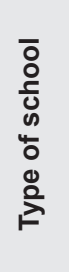 } & $\begin{array}{l}\text { Government } \\
\qquad(n=9)\end{array}$ & 3.4 & 0.9 & 3.4 & 1.3 & 3.4 & 0.9 & 3.2 & 0.5 & 3.9 & 1.0 & 3.1 & 0.7 & 3.0 & 0.8 \\
\hline & Church $(n=59)$ & 3.4 & 1.0 & 3.5 & 0.9 & 3.6 & 0.8 & 3.1 & 1.1 & 3.9 & 0.7 & 2.9 & 1.2 & 2.9 & 1.0 \\
\hline & $\begin{array}{l}\text { Community } \\
\qquad(n=5)\end{array}$ & 3.7 & 0.6 & 3.7 & 0.9 & 3.6 & 0.8 & 2.9 & 0.6 & 4.0 & 0.5 & 2.6 & 1.0 & 3.2 & 0.7 \\
\hline \multirow{4}{*}{ 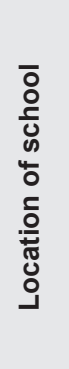 } & $\begin{array}{l}\text { Lowlands } \\
\qquad(n=64)\end{array}$ & 3.4 & 1.0 & 3.5 & 1.0 & 3.6 & 0.9 & 3.2 & 1.1 & 3.9 & 0.8 & 3.0 & 1.1 & 2.9 & 1.0 \\
\hline & $\begin{array}{l}\text { Highlands } \\
\qquad(n=8)\end{array}$ & 3.6 & 1.2 & 3.7 & 0.6 & 3.6 & 0.4 & 3.2 & 1.1 & 4.0 & 0.9 & 3.3 & 1.4 & 3.3 & 1.0 \\
\hline & $\begin{array}{l}\text { Rural areas } \\
\qquad(n=29)\end{array}$ & 3.6 & 1.0 & 3.6 & 0.8 & 3.4 & 0.5 & 3.3 & 1.0 & 4.0 & 0.8 & 3.5 & 1.4 & 3.4 & 0.7 \\
\hline & $\begin{array}{l}\text { Urban areas } \\
\qquad(n=43)\end{array}$ & 3.4 & 1.2 & 3.6 & 0.8 & 3.8 & 0.7 & 3.1 & 1.1 & 3.9 & 0.8 & 2.8 & 1.2 & 2.8 & 1.1 \\
\hline
\end{tabular}

The PCK mean scores for various groups of teachers ranged between 3.74 and 4.25 (table 3 ) and they were the highest. This shows that teachers had more PCK compared to the other types of knowledge. This is surprising because the teachers had to master content and pedagogy as the fundamental domains of knowledge before they could learn to integrate them (Ndongfack, 2015). The fact that PCK, CK and PK had the highest means $(3.89,3.55$ 
and 3.51 respectively) as shown in figure 2 indicates that teachers' professional development programmes probably focussed on content and pedagogy (Barujel et al., 2013).

The results in figure 4 also show that TK had a mean score of 3.37 while the mean scores for TPK, TCK and TPACK were 3.12, 2.93 and 2.88, respectively. TK had a higher mean than the types of knowledge that require integration of technology i.e. TPK, TCK and TPACK. This means that teacher education programmes may have focussed more on technology itself than on its integration into other types of knowledge (Koehler et al., 2013). All groups of teachers had means above the acceptable level of 3 for TK (table 3), with the exception of teachers aged 40 and above $(M=2.9)$. This suggests that most teachers have acquired satisfactory levels of technological training, either through pre-service or in-service education. It also suggests that the groups of teachers with a higher age were trained before technologies could be integrated into higher learning because technology is a relatively new phenomenon in developing countries (Khan, 2014). The mean scores for TCK and TPACK were higher for rural schools $\left(\mathrm{TCK}_{\mathrm{M}=3.5}, \mathrm{TPACK}_{\mathrm{M}=3.4}\right)$ than for schools in urban areas(M=2.8 for both), the feature that disputes Kalanda and De Villiers' (2013) claim that rural school teachers in Lesotho lag behind in terms of integrating ICTs.

\subsection{ANOVA for the hypothesis}

The $p$-values varied from 0.0130 to 0.9358 (table 4 ). The $p$-values for most domains of teachers' knowledge (33 out of 35) were above the significance level of $\alpha=0.05$ set for this paper (Bhattacherjee, 2012). These confirm a greater possibility that the findings obtained were a result of random variation and that there were no significant differences between different variables and groups of teachers (Aslan \& Zhu, 2016; Gelman, 2013). We therefore do not have sufficient evidence to reject the null hypothesis that high school teachers in Lesotho do not have the types of knowledge required for the integration of a variety of ICTs in their teaching. However, two of the 35 values are below 0.05 . These are the $\operatorname{TK}_{\text {age }}(p=0.013)$ and $\mathrm{PCK}_{\text {gender }}(\mathrm{p}=0.0218)$. These $\mathrm{p}$-values indicate a significant variation between the TK mean scores of different age groups of the teachers and between males and females in terms of their PCK (Greenland et al., 2016). The PCK mean scores for males $(M=3.7)$ and for females $(M=4.2)$ are both above the acceptable level of 3 , as a result they may not be a point of concern. However, the TK mean scores for teachers aged 40 and above $(M=2.9)$ may require some consideration.

Table 4: P-values for teachers' knowledge domains

\begin{tabular}{|l|c|c|c|c|c|}
\hline \multirow{2}{*}{$\begin{array}{c}\text { Domain of } \\
\text { knowledge }\end{array}$} & \multicolumn{5}{|c|}{ Probability values (p-values): } \\
\cline { 2 - 6 } & Age & Gender & Experience & School type & School location \\
\hline TK & 0.0130 & 0.1766 & 0.2942 & 0.7107 & 0.7363 \\
\hline PK & 0.5337 & 0.3785 & 0.5226 & 0.9156 & 0.8778 \\
\hline CK & 0.7517 & 0.4946 & 0.4886 & 0.7999 & 0.7009 \\
\hline TPK & 0.9358 & 0.2452 & 0.4854 & 0.8792 & 0.9194 \\
\hline
\end{tabular}




\begin{tabular}{|l|c|c|c|c|c|}
\hline \multirow{2}{*}{$\begin{array}{c}\text { Domain of } \\
\text { knowledge }\end{array}$} & \multicolumn{5}{|c|}{ Probability values (p-values): } \\
\cline { 2 - 6 } & Age & Gender & Experience & School type & School location \\
\hline PCK & 0.2795 & 0.0218 & 0.2207 & 0.9135 & 0.8925 \\
\hline TCK & 0.1765 & 0.5489 & 0.6834 & 0.7080 & 0.4978 \\
\hline TPACK & 0.4624 & 0.3530 & 0.2253 & 0.7478 & 0.5447 \\
\hline
\end{tabular}

\section{Conclusion}

Many physical science teachers in selected high schools of Lesotho use ICTs, even though they use them irregularly. Their use of ICTs for non-teaching activities is slightly higher than their use of ICTs for teaching. The teachers' ability to integrate technological knowledge into other types of knowledge needs to be improved for effective implementation of the new physical science curriculum, which demands the integration of ICTs. Measuring ICT integration into education is important because the amount and type of intervention required depends on the existing level of technological application (Du Toit, 2015). The lack of ICT assessment can lead to provision of far less assistance than is demanded.

Mobile networks have increased Lesotho's telephone density from $1 \%$ to $96 \%$ in the past 16 years (Morgan-Jarvis, 2015). The education system has to take advantage of this fact by promoting the integration of ICTs - especially mobile phones - into the curriculum. Mobile phones and other hand-held devices provide teachers with more accessible means of surfing the Internet. This paper highlights the technologies that are widely used so that they can be promoted.

The findings presented in this paper should be handled cautiously because of a few limitations. Firstly, this study was a survey characterised by a low response rate, thus a small sample. Secondly, schools were sampled rather than the individual teachers and this may have affected the sample representation of the population. However, the study is rendered resourceful, with valid findings, because the sample was representative enough of the teachers, covering five of the ten districts of Lesotho. The quantitative nature of the study also provided for a wider coverage of the population for more ideas and provision of a basis for more research. For instance, more research can be undertaken to examine how the use of mobile phones may be adopted in schools. Curriculum developers, in-service providers and teacher trainers may also use the findings of this study to improve their programmes and to form basis for their own research.

\section{References}

Abdullahi, H. 2014. The role of ICT in teaching science education in schools. International Letters of Social and Humanistic Sciences, 19, 217-223. DOI:10.18052/www.scipress.com/ ILSHS.19.217.

Alkahtani, A.A. 2016. The challenges facing participants in integration of ICT skills and equipment into the classrooms in SAUDI secondary schools. Social Science Learning Education Journal, 1, 39-47. 
Aslan, A. \& Zhu, C. 2016. Influencing factors and integration of ICT into teaching practices of pre-service and starting teachers. International Journal of Research in Education and Science, 2(2), 359-370. https://doi.org/10.21890/ijres.81048

Barujel, A.G., Morado, E.P. \& Pet, J.V. 2013. Technological pedagogical content knowledge of a computer engineering professor: A collaborative case study with the perspective of professor and researchers. Revista de Docencia Universitaria, 11, 349-374.

Bhattacherjee, A. 2012. Social science research: principles, methods, and practices. http:// scholarcommons.usf.edu/oa_textbooks/3 [Accessed 30 January 2012].

Chai, C., Chin, C., Koh, J. \& Tan, C. 2013. Exploring Singaporean Chinese language teachers' technological pedagogical content knowledge and it relationship to teachers' pedagogical beliefs. Asian-Pacific Researcher, 22(4), 657-666. https://doi.org/10.1007/s40299-013-0071-3

Chai, C.S., Koh, J.H.L., Tsai, C. \& Tan, L.L.W. 2011. Modelling primary school pre-service teachers' technological pedagogical content knowledge (TPACK) for meaningful learning with information and communications technology (ICT). Computers and Education. 57(2011):11841193. https://doi.org/10.1016/j.compedu.2011.01.007

Chere-Masopha, M.J. 2011. Integrating technology in classroom practices: the influence of teacher professional identities in secondary schools in Lesotho. Unpublished PhD thesis. Wollongong, NSW: University of Wollongong.

Chigona, A., Chigona, W. \& Davids, Z. 2014. Educators' motivation on integration of ICTs into pedagogy: Case of disadvantaged areas. South African Journal of Education, 34(3), 1-8. https://doi.org/10.15700/201409161051

Creswell, J.W. 2013. Steps in conducting a scholarly mixed methods study. http:// digitalcommons.unl.edu/dberspeakers/48 [Accessed 1 June 2013].

Drijvers, P., Tacoma, S., Besamusca, A., Doorman, M. \& Boon, P. 2013. Digital resources inviting changes in mid-adopting teachers' practices and orchestrations. Zentralblatt fur Didaktik der Mathematik, 45(7), 987-1001. https://doi.org/10.1007/s11858-013-0535-1

Du Toit, J. 2015. Teacher training and usage of ICT in education: New directions for the UIS global data collection in the post-2015 context. Background paper for ICT in education statistics. Paris: UNESCO Institute for Statistics.

Examinations Council of Lesotho. 2012. LGCSE physical science. Maseru: Ministry of Education and Training.

Examinations Council of Lesotho. 2013. COSC 2013 Pass List. Maseru: Ministry of Education and Training.

Farrell, G., Isaacs, S. \& Trucano, M. (Eds.). 2007. Survey of ICT and education in Africa 2: 53 Country Reports, 1-587. Washington DC: infoDev/World Bank.

Gelman, A. 2013. p-Values and statistical practice. Epidemiology, 24(1), 69-72. https://doi. org/10.1097/EDE.0b013e31827886f7

Greenland, S., Senn, S.J., Rothman, K.J., Carlin, J.B., Poole, C., Goodman, S.N. \&Altman, D.G. 2016. Statistical tests, $p$ values, confidence levels, and power: A guide to misinterpretations. European Journal of Epidemiology, 31, 337-350. DOI:10.1007/s0654-016-0149-3. 
Haddad, M.E.O., Ferreira, N.S.C. \& Faria, A.A. 2014. The use of educational technologies in distance education, enabling the appropriation of teaching and learning process. Journal of Social Sciences, 2, 54-58.

Harris, J.B. \& Hofer, M.J. 2011. Technological pedagogical content knowledge (TPACK) in action: a descriptive study of secondary teachers' curriculum-based, technology-related instructional planning. Journal of Research in Technology Education, 43(3), 211-229. https:// doi.org/10.1080/15391523.2011.10782570

Higgs, P. 1996. Metatheories in philosophy of education: an introductory overview. Pretoria: UNISA.

Johnson, R.B. \& Christensen, L. 2014. Educational research: quantitative, qualitative, and mixed approaches, 5th ed. Los Angeles: Sage Publications.

Kalanda, K. \& De Villiers, M.R. 2013. E-learning in the science curriculum: a study in selected high schools in Lesotho. Proceedings of World Conference on Educational Multimedia, Hypermedia and Telecommunications in Victoria, Canada. Association for the Advancement of Computing in Education (AACE). EdMedia.

Khan, S.H. 2014. A model for integrating technology into teacher training programs in Bangladesh based on TPCK. International Journal of Education and Development using Information and Communication Technology, 10(3), 21-31.

Koehler M.J. \& Mishra, P. 2008. Handbook of technological pedagogical content knowledge (TPCK) for educators. New York: Routledge.

Koehler, M.J., Mishra, P., Akcaoglu, M. \& Rosenberg, J.M. 2013. The technological pedagogical content knowledge framework for teachers and teacher educators. New York: Routledge.

Koohang, A. 2004. A study of users' perceptions towards e-learning courseware usability. International Journal of E-learning. 6(1):76-91. https://doi.org/10.1504/IJIL.2009.021685

Koohang, A. \& Harman, K. 2005. Open source: a metaphor for e-learning. Informing Science: The International Journal of an Emerging Transdiscipline. 8, 75-86. https://doi. org/10.28945/488

Koohang, A., Riley, L., Smith, T. \& Schreurs, J. 2009. E-Learning and constructivism: From theory to application. Interdisciplinary Journal of E-Learning and Learning Objects, 5, 91-109. https://doi.org/10.28945/66

Lau, B.T. \& Sim, C.H. 2008. Exploring the extent of ICT adoption among secondary teachers in Malaysia. International Journal of Computing and ICT Research, 2(2), 19-36.

Leedy, P.D. \& Omrod, J.E., 2013. Practical research: Planning and design, 10th edition. USA: Pearson Education.

Lesotho government. 2005. ICT policy for Lesotho final. 4 March 2005. Maseru: Government Printing.

Lesotho government. 2002. The Lesotho national vision 2020. Maseru: Government Printing. Lever-Duffy, J. \& McDonald, J.B. 2011. Teaching and learning with technology. Upper Saddle River, NJ: Pearson.

Maher, D. 2013. Pre-service primary teachers' use of iPads to support teaching: Implications for teacher education. Educational Research for Social Change, 2(1), 48-63. 
Mathers, N., Fox, N. \& Hunn, A. 2009. Surveys and questionnaires. Yorkshire: National Institute for Health Research Design Service for the Midlands.

Messina L. \& Tabone, S. 2012. Integrating technology into instructional practices focusing on teacher knowledge. Procedia-Social and Behavioural Sciences, 46, 1015-1027. DOI:10.1016/j.sbspro.2012.05.241

Mishra, P. \& Koehler, M.J. 2006. Technological pedagogical content knowledge: A framework for teacher knowledge. Teachers' College Record, 108(6), 1017-1054. https://doi. org/10.1111/j.1467-9620.2006.00684.x

Morgan-Jarvis, L. (Ed.). 2015. The Lesotho review: An overview of the kingdom of Lesotho's economy 2015 edition. Durban: Wade Publications.

Mouza, C., Karchmer-Klein, R., Ozden, S.Y. \& Hu, L. 2014. Investigating the impact of an integrated approach to the development of pre-service teachers' technological, pedagogical content knowledge (TPACK). Computers and Education, 71, 206-221. https://doi. org/10.1016/j.compedu.2013.09.020

Mulwa, A., Kyalo, N., Bowa, O. \& Mboroki, G. 2012. Influence of ICT infrastructure on readiness to adopt e-learning in secondary schools in Kitui District, Kenya. Journal of Continuing, Open and Distance Education, 2(1), i-229.

Ndongfack, N.M. 2015. TPACK constructs: A sustainable pathway for teachers' professional development on technology adoption. Creative Education, 6, 1697-1709. https://doi. org/10.4236/ce.2015.616171

Ntoi, L. 2007. Incorporating technology into the Lesotho science curriculum: investigating the gap between the intended and the implemented curriculum. Unpublished PhD thesis. Bellville: University of Western Cape.

Nwanekezi, A.U., Onyekuru, B. \& Oragwu, A.A. 2011. Reviewing science education curriculum through the integration of ICT practices: implications for scientific literacy. Journal of Emerging Trends in Educational Research and Policy Studies, 2(1), 53-59.

Olatokun, W. \& Ntemana, T.J. 2015. Information and communication technology (ICT) use by lecturers at the National University of Lesotho. Indian Journal of Library and Information Science, 9(1), 5-20. https://doi.org/10.21088/ijlis.0973.9548.9115.1

Peralta, H. \& Costa, F.A. 2007. Teachers' competence and confidence regarding the use of information and communications technology. SISIFO/Educational Sciences Journal, 3, 75-84.

Prasad, C.V.V.S.N.V., Lalitha, P. \& Strikar, P.V.N. 2015. Barriers to the use of information and communication technology (ICT) in secondary schools: teachers' perspectives. Journal of Management and Research, 7(2), 190-208. DOI:10.5296/jmr.v7i2.6935.

Rastogi, A. \& Malhotra, S. 2013. ICT skills and attitude as determinants of ICT pedagogy integration. European Academic Research, 1(3), 301-318.

SAS Institute Inc. 2013. SAS/STAT 13.1 user's guide. https://support.sas.com/documentation/ cdl/en/statug/66859/HTML/default/viewer.htm [Accessed 10 July 2013].

Schmidt, D.A., Baran, E., Thompson, A.D., Mishra, P., Koehler, M.J. \& Shin, T.S. 2009. Technological pedagogical content knowledge (TPACK): The development and validation of an assessment instrument for pre-service teachers. Journal of Research on Technology in Education, 42(2), 123-149. https://doi.org/10.1080/15391523.2009.10782544 
Shu, X.Y. 2016. An action research on TPACK's Influence on teachers of national open university exemplified with an English teacher of Zhejiang Radio and Television University. Open Access Library Journal, 3, e2336.

StatTrek. 2016. StatTrek random number generator. http://stattrek.com/statistics/randomnumber-generator.aspx [Accessed 04 February 2016].

Tavakol, M. \& Dennick, R. 2011. Making sense of Cronbach's alpha. International Journal of Medical Education, 2, 53-55. DOI:10.5116/ijme.4dbf.8dfd.

UNESCO. 2014. Information and communication technology (ICT) in education in Asia: A comparative analysis of ICT integration and e-readiness in schools across Asia. Paris: UNESCO Institute for Statistics. Information paper 22.

UNESCO. 2016. Communication and information. http://www.unesco.org/new/en/ communication-and-information/portals-and-platforms/goap/access-by-region/africa/lesotho/ [09 July Accessed 2016].

Vygotsky, L. 1978. Mind in society. London: Harvard University Press.

Wan, N. 2014. Flipping the science classroom: Exploring merits, issues and pedagogy. Journal of Australian Science Teachers Association, 60(3), 16-28.

Wang, Q. 2008. Ageneric model for the integration of ICT into teaching and learning. Innovations in Education and Teaching International, 45(4), 411-419. DOI:10.1080/14703290802377307.

Ward, L. 2003. Teacher practice and integration of ICT: why are not our secondary school teachers using computers in their classrooms? http://citeseerx.ist.psu.edu/viewdoc/ download?doi=10.1.1.128.7136\&rep=rep1\&type=pdf [Accessed 01 May 2015].

$\mathrm{Wu}, \mathrm{Y}$. 2013. Research trends in technological pedagogical content knowledge (TPACK) research: a review of empirical studies published in selected journals from 2002 to 2011 . British Journal of Educational Technology, 44(3), E73-E76. DOI:10.1111/j.1467-8535.2012.01349.x.

Zehra, R. \& Bilwani, A. 2016. Perceptions of teachers regarding technology integration in classrooms: A comparative analysis of elite and mediocre schools. Journal of Education and Educational Development, 3(1), 1-29. https://doi.org/10.22555/joeed.v3i1.709 